\title{
MASLAHAH SEBAGAI TEORI PENETAPAN HUKUM: TELAAH ATAS KONSEP MASLAHAH IBNU QAYYIM AL-JAUZIYAH
}

\author{
Dainori
}

STAI Miftahul Ulum Tarate Pandian Sumenep, Jawa Timur Email: dainoriiim@gmail.com

\begin{abstract}
In line with changes and the development of a society that is increasingly rapid, legal issues are increasingly complex. While every legal problem that develops in society is not all explicitly mentioned in the Koran, Hadith or ijma '. Whereas Islam as a religion must always be responsive and present to provide a solution to the growing legal problems. Mashlahah as one method of extracting the law is a suitable solution to address the legal problems that are developing at this time. However, so that the application of the mashlaah to explore and establish a law is not trapped in subjective matters and the interests of lust, then the use of these methods requires caution and understanding of the intact maqasid al-sharia and the use of strict mashlahah in accordance with the criteria that are Ulama 'Usul stipulated in order to achieve and find the law that is truly in accordance with the message of the law maker (shari'a).
\end{abstract}

Keywords: Mashlahah, Theory, Concepts.

\section{A. Pendahuluan}

Perlu diketahui bahwa syariah tidak menciptakan hukum-hukumnya dengan kebetulan, tetapi dengan hukum-hukum itu bertujuan untuk mewujudkan maksud-maksud yang umum. Kita tidak dapat memahami nashnash yang hakiki kecuali mengetahui apa yang dimaksud oleh syara' dalam menciptakan nash-nash itu. petunjuk-petunjuk lafadz dan ibaratnya terhadap makna sebenarnya, kadang-kadang menerima beberapa makna yang ditarjihkan yang salah satu maknanya adalah mengetahui maksud syara'.

Kaidah-kaidah pembentukan hukum Islam ini, oleh ulama ushul diambil berdasarkan penelitian terhadap hukum-hukum syara', illat-illatnya dan hikmah (filsafat) pembentukannya diantara nash-nash itu pula ada yang menetapkan dasar-dasar pembentukan hukum secara umum, dan pokok-pokok pembentukannya secara keseluruhan seperti juga halnya wajib memelihara dasar-dasar dan pokok-pokok itu dalam mengistimbath hukum dari nashnashnya, maka wajib pula memelihara dasar-dasar dan pokok-pokok itu dalam hal yang tidak ada nashnya, supaya pembentukan hukum itu dapat merealisasikan apa yang menjadi tujuan pembentukan hukum itu, dan dapat mengantarkan kepada merealisasikan kemaslahatan manusia serta menegakkan keadilan diantara mereka. ${ }^{1}$

${ }^{1}$ Lihat misalnya Untuk kajian tentang mashlahah lebih jauh, baca misalnya. Muhammad Roy Purwanto, Teori Hukum Islam dan Multikulturalisme (Jombang: Pustaka Tebuireng, 2016), h. 1; Muhammad Roy Purwanto, "Kritik Terhadap Konsep Mashlahah Najm Ad-Din At-Tufi", dalam MADANIAVol. 19, No. 1, Juni 2015, 29-48; Mahsun Fuad, Hukum Islam Indonesia, Yogyakarta, 2004, h. 18; Muhammad Roy Purwanto, Dekonstruksi Teori Hukum Islam: Kritik terhadap Konsep Mashlahah Najmuddin al-Thufi. (Yogyakarta: Kaukaba, 2014). 


\section{B. Pembahasan}

\section{B.1. Biografi Ibnu Qoyyim}

Nama lengkapnya Muammad bin Abi Bakr bin Ayyub bin Sa'ad bin Harris Az Zar'I Ad Damasqy. Laqabnya adalah Syamsuddin. Kunyahnya adalah abu Abdillah. Beliau lebih terkenal dengan panggilan Ibnu Qoyyim AlJuuziyyah. Beliau adalah putra seorang ulama pendiri madrasah " Al- Jauziat" di Damaskus. Ibnu Qoyyim Al-Jauziyyah dilahirkan pada tanggal 7 shafar $691 \mathrm{H}$ atau 4 Februari $1291 \mathrm{M}$ di sebuah desa pertanian yang disebut Hauran. Desa ini berada sekitar 55 mil, sebelah tenggara kota Damaskus, Suriah. Kemudian ia merantau ke Damaskus untuk mencari ilmu di sana. ${ }^{2}$

Dalam menimba ilmu pengetahuan Ibnu Qoyyim belajar kepada Ali Al Syihab al- Nablisi al-Qadir, Abi Bakar bin Abd al Daim al Qadhi al Din Salman, Isa al Mat'am. Ibnu Asakir dan gurunya yang paling berpengaruh baginya yaitu Ibnu Taimiyah. Justru Ibnu Qoyyim menyebarkan ilmu Ibnu Taimiyah tetapi tidak jarang berbeda pendapat dengan gurunya itu.

Ibnu qoyyim wafat di Damaskus pada tangal 13 Rajab 751 H/1350 M, sepertiga malam Kamis. Beliau di Makamkan di pemakaman al-Bab al-Shagir. Letaknya di samping madrasah al-Sabuniyah di sisi kiri jalan menuju pemakaman al-Bab as-Shagir dari arah pintu baru yang diperluas sejak 40 tahun lalu. ${ }^{3}$

Karya-karya Ibnu Qoyyim Al-Jauziyyah, diantaranya:4

1. Tuhfat al-Maudut bi Ahkami al-Maulud.

2. Miftah Daris Sa'adah.

3. A'lam al-Muwaqqi' in 'An Rabbi al-'Alamin.

4. Al-Jawab al-Kafi Liman Sa' ala 'an ad-Dawa'I as-Syafi.

5. Ighatsat al-Lahafan min Mashayidi as-Syaithan.

6. 'Uddatu ash-Shabirin wa Dzakhiratu as-Syakirin.

7. Raudhatu al-Muhibbin wa Nuzhatu al-Musytaqin.

\section{B.2. Konsep Maqāșid al-Sharī'ah Ibn Qayyim al-Jauziyyah}

Secara epistemologis, Ibn Qayyim tidak mempunyai buku utuh yang khusus membahas konsep maqāṣid, namun ia mempunyai beberapa buku yang dinilai oleh beberapa peneliti seperti Ismā'il al-Ḥasani, Jāser 'Audah, Aḥmad ibn Mas'ūd al-Yūbi, dan lain-lain sebagai buku praktis yang mengandung spirit maqāṣid. ${ }^{5}$ Di antaranya buku I'lam al-Muwaqqi'īn, Syifā' al-'Alīl, Aḥkām ahl alDhimmah, dan Zād al-Ma'ād. Salah satu bukti hal tersebut sebagaimana dikutip oleh al-Yūbi dalam bukunya Maqāṣid al-Sharī'ah al-Islāmiyyah wa 'Alāqatuhā bi al-Adillah al-Shar'iyyah adalah pandangan Ibn Qayyim terkait dengan konsep maslahat. ${ }^{6}$

462.

2Abu Muhammad Iqbal, Pemikiran Pendidikan Islam, (Yogyakarta: Pustaka Pelajar, 2015), h.

3Ibid., h. 463.

4Ibid., h. 463-464.

5Jāser 'Audah, Maqāṣidal-Sharī’ah 'Inda al-Shaykh al-Qarāḍawi, (Doha: t.pn, 2007), h. 15.

6Lihat misalnya. Muhammad Roy Purwanto dan Johari, Perubahan Fatwa Hukum dalam Pandangan Ibn Qayyim al-Jauziyyah (Yogyakarta: Universitas Islam Indonesia, 2017); Muhammad Roy Purwanto, Reformulasi Konsep Mashlahah sebagai Dasar dalam Ijtihad Istishlahi (Yogyakarta: Universitas Islam Indonesia, 2017). 
Ibn Qayyim berkata "Syariat Islam dibangun berdasarkan asas hikmah dan kemaslahatan manusia di dunia dan akhirat.Ia merupakan keadilan yang bersifat mutlak, kasih sayang, kemaslahatan, dan hikmah. Oleh karenanya, setiap persoalan yang bertolak belakang dari keadilan menuju kezaliman, kasih sayang menuju kekerasan, maslahat menuju kemudaratan, serta hikmah menuju sesuatu yang bernilai sia-sia, maka itu semua bukanlah bagian dari syariat, sekalipun ditafsirkan sebagai syariat. ${ }^{7}$

Selain itu ia juga menegaskan bahwa "Syariat Islam pada hakikatnya adalah keadilan, kasih sayang, perlindungan, serta kebijaksanaan Allah SWT terhadap para makhluk-Nya yang mencerminkan eksistensi dan kebenaran utusan-Nya, Muhammad SAW. Syariat Islam merupakan cahaya Allah yang dengannya manusia dapat melihat, petunjuk yang dengannya manusia memperoleh hidayah, obat penawar yang menjadi obat bagi mereka yang sakit, serta jalan lurus yang ditapaki oleh para pencari kebenaran. ${ }^{8}$

Terkait dengan ungkapan tersebut, Yūsuf al-Qarāḍawi berkomentar dalam bukunya Madkhal li Dirāsah al-Sharī'ah al-Islāmiyyah "Perkataan ini harus kita pegang teguh dan sodorkan terhadap mereka yang simpati terhadap Ibn Qayyim dan gurunya Ibn Taymiyyah, namun tidak membawa spirit dan pandangan ini (maslahat) dalam pemahaman keagamaan mereka. Pada dasarnya maslahat merupakan salah satu faktor penting dalam konsep perubahan fatwa karena disebabkan oleh perubahan ruang dan waktu yang mengitarinya. Sementara manusia pada hakikatnya harus menyesuaikan diri dengan tujuantujuan serta kemaslahatan-kemaslahatan yang digariskan oleh syariat lewat hukum- hukumnya."9

Berdasarkan data di atas dan data-data lain yang tersebar dalam bukubuku karyanya dapat diambil kesimpulan bahwa maqāșid al-sharī’ah perspektif Ibn Qayyim adalah kumpulan dari hikmah-hikmah dan kemaslahatan yang Allah turunkan bersama syariat-Nya untuk manusia, yang berasaskan keadilan universal serta kasih sayang yang bersifat umum dan paripurna. Ia juga menegaskan seandainya manusia mau memikirkan setiap perangkat hukum syariat yang Allah turunkan, niscaya mereka akan mendapati tidak satu pun dari hukum-hukum tersebut yang luput dari hikmah dan kemaslahatan. Ibnu qayyim juga menjelaskan bahwa tujuan hukum Islam adalah untuk mewujudkan kemashlahatan umat baik di dunia maupun di akhirat. Menurutnya, seluruh hukum itu mengandung keadilan, rahmat, kemashlahatan dan hikmah, jika keluar dari keempat nilai yang dikandungnya, maka hukum tersebut tidak dapat dinamakan Hukum Islam. ${ }^{10}$

\section{B.3. Kaedah-Kaedah Maqāṣid Ibn Qayyim al-Jauziyyah}

Di antara tema-tema besar maqāṣid sharī' ah yang menjadi konsentrasi Ibn Qayyim dalam karya-karyanya adalah sebagai berikut:

7Ibn Qayyim al-Jauziyyah, I'lām al-Muwaqqi'īn 'an Rabb al-'Ālamīn, (Mesir: Dār al-Ḥadīth, 2006), vol. 2, h. 5.

8Ibid.,.

${ }^{9}$ Yusūf al-Qarāḍowi, Madkhal li Dirāsah al-Sharī'ah al-Islāmiyah, (Beyrūt: Muassasah alRisālah, 1993), cet. 1, h. 9.

10Ibn Qayyim al-Jauziyyah, Syifā' al-'Alīl fi Masāil al-Qaḍa wa al-Qadr wa al-Hikmah wa alTa'līl, (Beyrūt: Dār al-Ma' rifah, 1978), cet. 1, vol. 1, h. 229. 


\section{Ta'līl al-Aḥkām dan Hikmah al-Tashri' serta relasinya dengan Maqāṣid}

Ta'lil secara etimologi adalah berasal dari kata-kata 'allala-yu'alliluta'līl,dari kata dasar al-'illu yang bermakna tegukan atau hisapan kedua. Secara terminologi ta'lil al-ạ̣kam adalah titik fokus dalam proses ijtihad dan istimbat (proses penggalian hukum-hukum syariat dari sumbersumbernya yang utama), yang mana keberadaannya menjadi penentu terungkapnya rahasia-rahasia syariat serta hikmah-hikmahnya. Selain itu, ta'lìl al-ahkam juga berfungsi sebagai wasīlah (perantara) direalisasikannya sebuah hukum syariat dalam kondisi-kondisi yang berbeda sesuai dengan ada tidaknya illat yang mengitari hukum tersebut. Sebuah kaedah populer menyebutkan bahwa hukum syariat berlaku sesuai dengan illatnya. Ia akan ada manakala ditemukan illatnya dan begitupun sebaliknya. ${ }^{11}$

Ibn al-Qayyim memberikan perhatian yang cukup besar terhadap tema ini. Ia secara kritis membantah mereka yang tidak mengakui adanya ta'lil al-ạ̣kam. Ia menegaskan "menetapkan bahwa Allah menurunkan syariat dengan hikmah merupakan cermin kesempurnaan, sementara menegasikannya dari Allah adalah sifat kekurangan. Padahal para ulama sepakat mengatakan bahwa Allah maha suci dari segala kekurangan. Dalam bukunya Madārij al-Sälikīn, ia juga mengutarakan keheranannya terhadap mereka yang mengingkari ta'lì al-ạ̣kam pada hukum-hukum syariat. Bagaimana mungkin Allah menurunkan sesuatu hukum tertentu namun kosong dari maksud dan tujuan.Hal ini menurutnya adalah sebuah perkara yang mustahil bagi Allah SWT. ${ }^{12}$

Sementara itu titik perbedaan Ibn Qayyim dalam hal ini dengan para pemikir maqāṣid sebelumnya hanya terletak pada universalitas ta'lì yang dia anut. Ibn Qayyim cendrung berpendapat bahwa semua hukumhukum syariat mempunyai illat tanpa terkecuali. Baik hukum muamalah, adat, dan begitu juga dengan ibadah, semuanya mempunyai ta'lil al-shar'i, walaupun akal kita tidak bisa menangkap sebagian dari illat dan hikmah tersebut. Hal ini senada dengan apa yang juga diyakini oleh gurunya Ibn Taymiyyah. Namun mayoritas ulama seperti al-Juwayni, al-Ghazāli, 'Izzu al-Dīn ibn 'Abd al-Salām, al-Shațibi, Ibn Ashūr, Abd al-Wahhab al-Khalāf dan lain-lain cendrung berpendapat sebaliknya. Bagi mereka tidak semua hukum syariat mempunyai illat.Mereka menegaskan bahwa maksud dan tujuan utama ibadah adalah penyerahan diri secara total kepada Allah serta tunduk dan patuh terhadap segala perintah-Nya, tanpa harus mengkaji makna ataupun illat hukumnya. ${ }^{13}$

11Zuhratul 'Aini, Manhaj Ibn Qayyim al-Jauziyyah fi Ta'lī al-Ahkām, (tesis S-2 Fakultas Syariah dan Hukum, Universitas al-Azhar Mesir, 2009), h. 76-75.

12Abdullah ibn Abd al-Raḥmān al-Bassam dan Ibrāhīm ibn Muhammad al-Hamd al-' Ali alJaṭili, Asrār al-Sharī'ah min I'lām al-Muwaqqi'ìn, (Riyāẹ : Dār al-Musayyar, 1998), cet. 1, h. 15.

${ }^{13} \mathrm{Izz}$ al-Dīn ibn Abd al-Salām, Qawā'id al-A ḥām fi Maṣālih al-Anām, (Beyrūt: Dār al-Qalam, 2010), cet. 4, vol. 1, 28; Lebih jauh tentang ta'lil lihat misalnya. Muhammad Roy, Ushul Fiqih Madzhab Aristoteles: Pelacakan Logika Aristoteles dalam Qiyas Ushul Fiqih, (Yogyakarta: Safiria, 2004). Lihat juga. Muhammad Roy Purwanto, "Nalar Qur'ani al-Syâfi'i dalam Pembentukan Metodologi Hukum: Telaah Terhadap konsep Qiyas", dalam An-Nur: Jurnal Studi Islam, Vol. 1, No.1, September 2004, 1; Muhammad Roy Purwanto, Pemikiran Imam al-Syafi'i dalam Kitab al-Risalah 
2. Darūriyyah al-Khams dan pengembangannya menurut Ibn Qayyim al-Jauziyyah

Para ulama uṣul klasik sepakat bahwa maqāṣid sharī'ah atau yang disebut juga dengan al-kulliyyah al-Khams oleh al-Ghazāli -yaitu menjaga agama, jiwa, akal, keturunan, dan harta benda- adalah bersifat pasti dan tetap berdasarkan dalil dari Al-Qur'an dan Hadis. al-Ghazāli dalam kitabnya al-Mustașfa menyatakan bahwa tujuan syariat untuk manusia secara umum ada lima, yaitu untuk memelihara agama, diri, akal, keturunan, dan harta mereka."

Namun Ibn Qayyim mempunyai pandangan tersendiri terkait dengan tema al-kulliyat al-khams. Bagi dia, maqāșid sharīah tidak hanya terbatas kepada 5 hal tersebut, bahkan lebih dari itu. Tujuan utama syariah sebenarnya adalah peneguhan diri untuk menyembah Allah SWT semata. ${ }^{14}$

Menurut al-Jundi setidaknya ada 7 kaedah tambahan yang diusulkan oleh Ibn Qayyim, yaitu:

1. Mengenal Allah dengan seluruh nama dan sifat-Nya serta senantiasa mencintai dan menyembah-Nya.

2. Menegakkan keadilan, menjauhi sifat zalim, sombong, syirik, dan permusuhan.

3. Menolak tipu daya setan dan mematuhi perintah Tuhan.

4. Bersifat benar, sabar, dan bersyukur.

5. Bersifat pemalu, beradab, dan berakhlak yang mulia.

6. Menjaga lingkungan serta menyeru orang lain untuk meningkatkan perhatian terhadap pendidikan yang berbasis lingkungan.

7. Mempererat persatuan dan menghindari perpecahan. ${ }^{15}$

Hal ini sama persis dengan pandangan gurunya yang juga mengembangkan kulliyah al- khams kepada kaedah-kaedah lainnya. Seperti kaedah kritis terhadap orang-orang kafir dan tidak menyerupai kebudayaan mereka.Tidak mengikuti langkah-langkah setan dan mereka yang tidak menyempurnakan kewajiban agamanya. Membudayakan sikap toleransi, sifat sabar, berani, dan akhlak mulia. Memperkuat persatuan dan menghindari perpecahan. Senantiasa mendakwahkan Islam, berjihad karena Allah dan saling tolong-menolong dalam hal tersebut. Bersifat adil dan menjauhi sifat zalim. Tidak memperturutkan hawa nafsu serta menuntunnya agar senantiasa patuh terhadap perintah Allah SWT.16

\section{Jalb al-Mașālih wa Dar'u al-Mafāsid dan Relasinya dengan Maqāṣid}

Kaedah ini termasuk kaedah pokok dan mendasar dalam Ilmu Maqāṣid. Al-Șhațibi menegaskan bahwa Allah dalam syariat-syariat yang Ia turunkan selalu memprioritaskan kemaslahatan manusia, baik untuk dunianya maupun akhirat. Setiap orang yang mengingkari fakta ini, dianggap keliru dan kata-katanya tertolak secara otomatis. Ibn Qayyim

tentang Qiyas dan Perkembangannya dalam Ushul Figh, (Yogyakarta: Universitas Islam Indonesia, 2017); Muhammad Roy Purwanto, Filsafat Yunani dalam Ushul Figh (Yogyakarta: Kaukaba, 2016).

14Ibn Qayyim al-Jauziyyah, Miftāḥ Dār al-Sa'ädah, (Beyrūt: Dār al-Kutub al-'Ilmiyyah, t.t), vol. 2, h. 119.

15al-Jundi, Maqāṣidal-Sharī'ah 'Inda Ibn Qayyim al-Jauziyyah, h. 224-244.

16Yūsuf Aḥmad Muhạmmad al-Badawi, Maqāṣidal-Sharī'ah 'Inda Ibn Taymiyyah,(Jordania: Dār al- Nafāis, 2000), cet. 1, h. 265-267. 
beragumen bahwa setiap hal yang ditetapkan Allah pada hakikatnya adalah baik, apalagi Allah tidak akan mungkin menyeru kepada hal-hal yang membawa kepada kemudaratan dan kebinasaan. ${ }^{17}$

Di samping itu ia juga cendrung kepada pendapat yang mengatakan bahwa kebaikan dan keburukan sudah tetap sejak alam ini diciptakan. Diharamkannya minuman keras, mengundi nasib dengan anak panah, berjudi, berzina, dan perbuatan keji lainnya merupakan aturan yang sudah tetap dan baku jauh sebelum diturunkannya al-Qur'an kepada Nabi Muhammad SAW dan lebih ditegaskan lagi setelah ayat yang melarang hal-hal keji tersebut diwahyukan kepadanya. ${ }^{18}$ Namun yang menjadi persoalan adalah bagaimana proses penentuan antara kemaslahatan dan kemudaratan secara pasti, padahal itu merupakan perkara yang samar dan berbeda di antara masing-masing orang. ${ }^{19}$

Ibn 'Abd al-Salām dalam Qawā'id al-Aḥkām-nya menjawab bahwa penentuan hal tersebut bergantung kepada sangkaan kuat yang muncul dalam ijtihad seseorang mujtahid, karena hal ini sebenarnya tergolong relatif sehingga tidak dapat dipastikan. Seorang mujtahid hanya bisa melihat faktor-faktor dan gejala-gejala lahiriah semata, adapun hakikatnya hanya sang pembuat syariatlah yang mengetahuinya. Ia berpendapat bahwa hakikat kemaslahatan itu terdiri dari 4 unsur yaitu kesenangan dan sebab-sebabnya serta kebahagian dan sebab-sebabnya, sama seperti kemudaratan yang tersusun dari kepedihan dan sebabsebabnya serta kesusahan dan faktor-faktor yang melatarbelakanginya. ${ }^{20}$

Seorang ahli ibadah tidak bisa memastikan bahwa hidupnya akan berakhir dengan husn al-khātimah, namun mereka beramal berdasarkan atas sangkaan kuat yang bersemayam dalam hati sanubari, dan mereka bersamaan dengan hal itu khawatir kalau apa yang mereka amalkan tidak diterima oleh Allah SWT. Seperti itu juga halnya dengan seorang pekerja, mereka beraktivitas berdasarkan sangkaan kuat akan adanya untung setelah bekerja, padahal mungkin saja yang terjadi sebaliknya. ${ }^{21}$

Kemudian, seandainya ada sebuah perkara yang kadar kemaslahatan dan kemudaratannya belum bisa diketahui secara pasti, maka kita tidak bisa mengunggulkan salah satu di antara keduanya terhadap yang lain kecuali setelah tampak unsur kemaslahatannya, atau minimal kemaslahatannya lebih besar dari kemudaratannya. Sehingga dari beberapa faktor di atas, muncullah kaedah lain yang menyebutkan bahwa fatwa akan berubah seiring perubahan faktor-faktor yang melatarbelakanginya berupa waktu, tempat, kondisi, niat, dan situasisituasi tertentu lainnya, termasuk perubahan kemaslahatan yang mengiringinya. Hal ini dijelaskan secara panjang lebar oleh Ibn Qayyim alJauziyyah dalam bukunya I'lam al-Muwaqqi'in 'an Rabb al-'Alamin.

\footnotetext{
17al-Jundi, Maqāṣidal-Sharī'ah 'Inda Ibn Qayyim al-Jauziyyah..., h. 258.

18Ibid., 254.

${ }^{19}$ Adanya pertentangan karena adanya perbedaan penafsiran ulama dalam hal fiqh. Lihat misalnya, Muhammad Roy Purwanto, "Different Qiraat and Its Implication in Differerent Opinion of Islamic Jurisprudence", dalam Jurnal al-Mawarid, Vol. 8. Nomor 2. 2013.

${ }^{20}$ Izz al-Dīn ibn Abd al-Salām, Qawā'id al-Aḥkām fì Maṣālih al-Anām..., vol. 1,h. 6-15.

21 Ibid., h. 6.
} 


\section{B.4. Contoh Aplikasi Maqāṣid Ibn Qayyim dalam Pemahaman Hadis}

Dalam sub bahasan ini, penulis akan menampilkan beberapa hadis nabawi yang oleh Ibn Qayyim dipahami berdasarkan paradigm maqāṣid yang ia rumuskan. Di antaranya: Hadis tentang larangan memerangi para oknum pemerintah yang melalaikan salat dari waktunya. Seperti hadis yang diriwayatkan oleh Muslim dan Abū Dāūd yang berasal dari Ummi Salamah bahwasanya Rasulullah SAW bersabda:

"Akan datang para penguasa, kalian mengenal mereka namun kalian mengingkari (perbuatan) mereka. Siapa yang tau dengan kemungkarannya hendaklah berlepas diri dan barangsiapa yang mengingkarinya maka ia telah selamat. Akan tetapi bagi yang rida dan mengikuti, para sahabat langsung menyela "bagaimana kalau kita perangi saja mereka?" lalu beliau menjawab "jangan, selama mereka mendirikan salat."

Dan juga hadis riwayat al-Bukhāri, Muslim, Abū Dāūd, dan Aḥmad yang bersumber dari Ibn 'Abbas, ia berkata:

"Barangsiapa yang melihat pada diri pemimpinnya ada sesuatu yang ia benci hendaknya ia bersabar, sebab siapa yang memisahkan diri dari jama'ah walau sejengkal kemudian dia mati, maka matinya seperti mati jahiliyah."

Hadis ini menjelaskan tentang tatacara merespon kemungkaran supaya kemungkaran tersebut berubah menjadi kebaikan yang dikehendaki oleh Allah dan Rasulullah. Ibn Qayyim menggaris bawahi melalui paradigma maqāṣidnya bahwa apabila ada sebuah respon terhadap kemungkaran, namun akan menimbulkan efek yang lebih parah dari yang sudah ada, maka mengingkari perkara seperti ini sebaiknya tidak dilakukan, sekalipun Allah membenci perbuatan itu dan para pelakunya. Hal ini seperti mengingkari kebijakan para raja dan pemimpin dengan cara tidak mengikuti kebijakan mereka atau meninggalkan mereka. Karena hal itu merupakan sumber segala kejahatan dan fitnah hingga akhir zaman. Seandainya semua orang memikirkan secara mendalam apa yang tersirat dalam aturan syariat yang seperti ini, niscaya ia akan menyadari bahwa ketidaksabaran dalam mengubah suatu kemungkaran serta bersikap radikal terhadap para pelakunya tidak akan menyelesaikan persoalan bahkan itu dapat saja memperparah situasi. ${ }^{22}$

Selanjutnya Ibn Qayyim menganalogikan hal ini dengan apa yang pernah dilakukan oleh Rasulullah ketika melihat berbagai macam kemungkaran di tanah Mekah dan beliau pada saat itu merasa belum sanggup untuk mengubahnya. Bahkan pada saat penaklukan kota Mekah sekalipun menjadi kampung muslim, Rasulullah pernah bercita-cita untuk merubah bangunan Ka'bah dan mengembalikannya ke bentuk semula sebagaimana adanya pada masa Nabi Ibrahim AS. Namun Rasulullah tidak melakukan itu semua, padahal secara kekuatan umat Islam sanggup untuk memberantas semua kemungkaran yang ada karena khawatir munculnya kemudaratan yang lebih besar yaitu kembalinya mereka kepada tradisi lama (baca murtad) lantaran belum bisa menerima aturanaturan baru agama Islam.

Oleh karena itu, dapat disimpulkan bahwa Rasulullah sekali lagi tidak mengizinkan umatnya untuk mengkritik pemerintah dengan cara yang radikal, karena bisa saja hal itu akan menimbulkan kemudaran yang lebih besar.

22Ibn Qayyim al-Jauziyyah, I'lām al-Muwaqqi'īn 'an Rabb al-'Ālamīn, vol. 3..., h. 6. 
Paradigma seperti ini muncul dari prinsip jalb al-mașaliḥ wa dar'u al-mafāsid (mencapai kemaslahatan dan menghindari kemudaratan) sebagaimana yang dijelaskan oleh Ibn Qayyim dalam beberapa karyanya di atas. Akan tetapi logika berfikir seperti ini sangat kontras dengan apa yang tercermin dalam tradisi sebagian kelompok atau ormas-ormas Islam yang mengatasnamakan diri sebagai "pengawal agama" di Negeri ini. Mereka bersikap keras dan terlalu radikal terhadap para pelaku kemaksiatan. Padahal kalaulah saja mereka lebih bersikap sabar dan lemah lembut dalam usaha meminimalisirnya, niscaya akan menghasilkan perubahan yang lebih baik buat masyarakat dan agama Islam sendiri. Selain itu tindakan radikal seperti itu telah memperburuk citra masyarakat muslim di mata dunia, bahkan hari ini umat Islam telah dicap sebagai umat penebar teror buat masyarat dunia. Tentu saja hal ini akan memperburuk citra serta menjauhkan umat Islam dari nilai-nilai keislaman sebagaimana yang diajarkan oleh Allah SWT dalam al-Qur'an dan Rasulullah dalam hadis-hadisnya.

Ibn Qayyim telah memetakan empat kategori dalam hal merespon sebuah kemungkaran. Pertama, respon yang akan menghilangkan kemungkaran tersebut dan mengubahnya menjadi kebajikan-kebajikan. Kedua, respon yang menyebabkan sebagian kemaksiatan berkurang walaupun tetap menyisakan sebagiannya. Ketiga, respon yang mengakibatkan kemaksiatan tersebut berubah menjadi kemaksiatan lain yang serupa. Dan yang keempat, respon yang mengakibatkan munculnya kemudaratan baru yang lebih parah. Dua kategori yang pertama sangat dianjurkan oleh agama. Sementara itu kategori ketiga masih berada dalam ranah khilāfiah ulama', sebagian mereka membolehkan dan sebagian yang lain melarangnya. Sedangkan kategori keempat diharamkan oleh agama, lantaran efek negatif yang akan ditimbulkannya. ${ }^{23}$

Selain itu, Ibn Qayyim juga menceritakan kisah gurunya Ibn Taymiyyah ketika melewati sebuah negeri bersama sahabat-sahabatnya pada zaman kerajaan Tatar.Sebagian penduduknya mempunyai kebiasaan mabuk-mabukan dan perbuatan maksiat lainnya. Karena tidak sabar dengan hal itu, salah seorang sahabat Ibn Taymiyyah mencoba untuk menegur perbuatan mereka, namun anehnya Ibn Taymiyyah malahan melarangnya seraya berkata:

"Allah mengharamkan khamar karena ia bisa melupakan seseorang terhadap Tuhan serta kewajiban-kewajibannya selaku hamba-Nya, sementara perbuatan tersebut (meminum khamar) dapat menghentikan mereka dari perbuatan keji lainnya seperti membunuh, merampok, dan lain-lain. Oleh sebab itu biarkanlah mereka!"24

\section{Simpulan}

Kesimpulan dari kajian ini adalah bahwa Ibn Qayyim al-Jauziyyah memberi perhatian lebih terhadap konsep ta'līl al-aḥkām,hikmah al-tashri', dan pengembangan kaedah kulliyyat al-khams kepada kaedah-kaedah lainnya seperti kaedah mengenal Allah dengan seluruh nama dan sifat-Nya serta senantiasa mencintai dan menyembah-Nya, menegakkan keadilan, menjauhi sifat zalim, sombong, syirik, dan permusuhan, menolak tipu daya setan dan mematuhi perintah Tuhan, bersifat benar, sabar, dan bersyukur, serta kaedah-

${ }^{23} I b n$ Qayyim al-Jauziyyah, I'lām al-Muwaqqi'īn 'an Rabb al-' Ālamīn, vol. 3..., h. 7.

24Ibid., h. 6. 
kaedahlainnya. Di samping itu Ibn Qayyim juga menjelaskan tentang prinsip jalb al-mașaliḥ wa dar'u al-mafāsid (mencapai kemaslahatan dan menghindari kemudaratan) yang mana telah beliau jelaskan panjang lebar dalam bukunya I'lam al-Muwaqqi' in 'an Rabb al-'Alamin.

\section{Referensi:}

Abdullah ibn Abd al-Raḥmān al-Bassam dan Ibrāhīm ibn Muhammad al-Ḥamd al-'Ali al-Jațili,

1998 Asrār al-Sharī'ah min I'lām al-Muwaqqi'īn, Riyāụ : Dār al-Musayyar, cet. 1.

'Aini, Zuhratul, 2009, Manhaj Ibn Qayyim al-Jauziyyah fi Ta'līl al-Aḥkām, tesis S2 Fakultas Syariah dan Hukum, Universitas al-Azhar Mesir.

al-Jauziyyah, Ibn Qayyim, 2006 I'lām al-Muwaqqi'īn 'an Rabb al-'Ālamīn, Mesir: Dār al- Ḥadīth. 1978, Syifā' al-'Alīl fi Masāil al-Qaḍa wa al-Qadr wa al-Hikmah wa al-Ta'līl, Beyrūt: Dār al-Ma'rifah, , cet. 1, vol.1.

al-Qarāḍowi,Yusūf, 1993, Madkhal li Dirāsah al-Sharīah al-Islāmiyah, Beyrūt: Muassasah al-Risālah.

Audah, Jāser, 2007, Maqāṣidal-Sharī'ah 'Inda al-Shaykh al-Qarāọawi, Doḥa: t.pn.

Ibn Abd al-Salām, 'Izz al-Dīn, 2010, Qawā'id al-Aḥkām fī Mașālih al-Anām, Beyrūt: Dār al-Qalam, cet. 4, vol.1.

Iqbal, Abu Muhammad, 2015, Pemikiran Pendidikan Islam, Yogyakarta: Pustaka Pelajar,

Muhammad al-Badawi, Yūsuf Aḥmad, 2000, Maqāṣidal-Sharī'ah 'Inda Ibn Taymiyyah, Jordania: Dār al-Nafāis, , cet. 1.

Roy, Muhammad, Ushul Fiqih Madzhab Aristoteles: Pelacakan Logika Aristoteles dalam Qiyas Ushul Fiqih, (Yogyakarta: Safiria, 2004).

Purwanto, Muhammad Roy, “Nalar Qur'ani al-Syâfi'i dalam Pembentukan Metodologi Hukum: Telaah Terhadap konsep Qiyas", dalam An-Nur: Jurnal Studi Islam, Vol. 1, No.1, September 2004.

Purwanto, Muhammad Roy, "Hukum Islam dan Hukum Adat Masa Kolonial: Sejarah Pergolakan antara Hukum Islam dan Hukum Adat Masa Kolonial Belanda" dalam An-Nur: Jurnal Stud Islam, Vol. 1. Nomor. 2. Februari 2005.

Purwanto, Muhammad Roy, "Different Qiraat and Its Implication in Differerent Opinion of Islamic Jurisprudence", dalam Jurnal al-Mawarid, Vol. 8. Nomor 2. 2013.

Purwanto, Muhammad Roy, Dekonstruksi Teori Hukum Islam: Kritik terhadap Konsep Mashlahah Najmuddin al-Thufi. (Yogyakarta: Kaukaba, 2014).

Purwanto, Muhammad Roy, "Kritik Terhadap Konsep Mashlahah Najm Ad-Din At-Tufi", dalam MADANIAVol. 19, No. 1, Juni 2015.

Purwanto, Muhammad Roy, Teori Hukum Islam dan Multikulturalisme (Jombang: Pustaka Tebuireng, 2016).

Purwanto, Muhammad Roy, Filsafat Yunani dalam Ushul Fiqh (Yogyakarta: Kaukaba, 2016).

Purwanto, Muhammad Roy dan Johari, Perubahan Fatwa Hukum dalam Pandangan Ibn Qayyim al-Jauziyyah (Yogyakarta: Universitas Islam Indonesia, 2017). 
Purwanto, Muhammad Roy, Pemikiran Imam al-Syafi'i dalam Kitab al-Risalah tentang Qiyas dan Perkembangannya dalam Ushul Fiqh, (Yogyakarta: Universitas Islam Indonesia, 2017.

Purwanto, Muhammad Roy, Reformulasi Konsep Mashlahah sebagai Dasar dalam Ijtihad Istishlahi (Yogyakarta: Universitas Islam Indonesia, 2017). 